САВЧЕНКО Ирина Александровна - доктор социологическихнаук, доцент, начальникмеждународной междисциплинарной научной лаборатории технологий социально-гуманитарных исследований, профессор кафедры философии, социологии и теории социальной коммуникации Нижегородского государственного лингвистического университета им. Н.А. Добролюбова (603155, Россия, г. Нижний Новгород, ул. Минина, 31a); профессор кафедры психологии и педагогики Нижегородской академии МВД РФ (603144, Россия, г. Нижний Новгород, Анкудиновское ш., 3; teosmaco@rambler.ru)

УСТИНКИН Сергей Васильевич - доктор исторических наук, профессор; декан Высшей школы международных отношений и мировой политики, директор международной междисииллинарной научно-исследовательской лаборатории изучения мировых и региональных социально-политических процессов Нижегородского государственного лингвистического университета им. Н.А. Добролюбова (603155, Россия, г. Нижний Новгород, ул. Минина, 31a); директор Приволжского филиала ФНИСЦ РАН (603000, Россия, г. Нижний Новгород, Холодный nер., 4; sv.ustinkin@gmail.com)

\title{
ЯЗЫКОВАЯ ПОЛИТИКА И ЛИНГВИСТИЧЕСКАЯ БЕЗОПАСНОСТЬ
}

\begin{abstract}
Аннотация. Авторы раскрывают основные вопросы, обсуждавшиеся в рамках международного научнообразовательного форума «Языковая политика и лингвистическая безопасность», который состоялся 1-2 октября 2020 г. в Нижнем Новгороде. В статье показывается значимость и актуальность исследовательских проблем, осмысленных и концептуализированных в ходе научной дискуссии.

Ключевые слова: языковая политика, лингвистическая безопасность, лингвистический анализ, социальная ответственность, социолингвистика, этнография разговорной речи, русский язык, идентичность, историческая память, семантика
\end{abstract}

$\mathrm{B}_{\mathrm{y}}^{\mathrm{H}}$ начале октября 2020 г. Нижегородский государственный лингвистический университет им. Н.А. Добролюбова принимал участников Четвертого международного научно-образовательного форума «Языковая политика и лингвистическая безопасность».

Форум проходил под председательством ректора НГЛУ Ж.В. Никоновой. В качестве сопредседателя форума выступил президент НГЛУ Б.А. Жигалев. В оргкомитет форума вошли председатель Комитета Государственной думы РФ по образованию и науке Вячеслав Алексеевич Никонов, министр образования, науки и молодежной политики Нижегородской области Сергей Васильевич Злобин, митрополит Нижегородский и Арзамасский Георгий, а также ректоры российских и зарубежных лингвистических вузов.

К организации трековых сессионных заседаний были привлечены руководители международных научно-исследовательских лабораторий (ММ НИЛ), действующих на базе НГЛУ, в частности начальник ММ НИЛ «Технологии социально-гуманитарных исследований профессор И.А. Савченко и начальник ММ НИЛ «Изучение мировых и региональных социально-политических процессов» С.В. Устинкин.

На форуме были представлены доклады и сообщения, в которых обсуждались различные аспекты изучения и функционирования языка как социокультурного феномена. Была предпринята попытка теоретического осмысления и практической реализации языковой политики на региональном, национальном, глобальном уровнях. Поднимались вопросы рефлексии лингвистической безопасности в контексте актуальных социокультурных трансформаций; выявления тенденций языковой политики в мире и на постсоветском пространстве; концептуализации роли русского языка в обеспечении национальной безопасности и международного сотрудничества РФ; изучения языковых и демогра- 
фических аспектов современных миграционных процессов; понимания роли национальных языков в глобальном мире.

Так, в рамках изучения языковых процессов в лингвополитическом измерении доктор филологических наук, профессор, ректор Нижегородского государственного лингвистического университета им. Н.А. Добролюбова Жанна Викторовна Никонова и кандидат филологических наук доцент Нижегородского государственного национального исследовательского университета им. Н.И. Лобачевского Елена Вячеславовна Соловьева раскрыли проблемные вопросы лингвистического анализа текстов типа «фейк ньюс». На примере немецкого политического дискурса докладчики показали, каким образом лингвистические характеристики текста влияют на его восприятие в массовом сознании.

Методологические вопросы исследования социокультурной миссии языка в контексте истории и современности предложил обсудить доктор социологических наук профессор Марек Соколовски (Варминьско-Мазурский университет в г. Ольштыне, Польша). Докладчик представил концептуальное обоснование новых направлений социокультурных исследований языка. Профессор Соколовски показал, почему в настоящее время актуальной становится этнография разговорной речи в противовес классической социолингвистике. Можно сказать, что Марек Соколовски на долгие годы вперед обозначил магистральные ориентиры для лингвокультурных исследований в рамках современной социально-гуманитарной науки.

Доктор социологических наук профессор Армен Коляевич Саакян (Ереванский филиал Российского экономического университета им. Г.В. Плеханова) также обратился к этнографии языка и раскрыл роль и значение арамейского языка в судьбе народов. Лингвистический и духовный след арамейского языка А.К. Саакян обнаруживает в культурах и религиях многих народов.

О ценностной природе языка шла речь в докладах представителей Московского городского педагогического университета - кандидата филологических наук доцента Оксаны Васильевны Казаченко и старшего преподавателя Ольги Вячеславовны Ковальчук. Так, О.В. Казаченко раскрыла особенности экспликации ценностей в контексте языковой безопасности, а О.В. Ковальчук проблему трансформации ценностно-смысловой составляющей публичного дипломатического дискурса.

Докладчики подчеркивали, что проблема лингвистической безопасности тесно связана с другими значимыми явлениями общественной жизни. Так, доктор филологических наук, профессор, ведущий научный сотрудник сектора этнопсихолингвистики Института языкознания РАН Мария Александровна Пильгун представила концептуальное обоснование взаимосвязи и взаимовлияния социальной ответственности и лингвистической безопасности и показала, почему необходимо отказаться от изолированного рассмотрения этих феноменов.

Ряд докладчиков акцентировали внимание на взаимодетерминациях лингвистической идентичности, языковой политики и исторической памяти. Доктор социологических наук профессор Галина Сергеевна Широкалова (Федеральный научно-исследовательский социологический центр РАН, Нижегородский государственный лингвистический университет им. Н.А. Добролюбова) представила системную концепцию языка как формы социальной идентичности, показав, сколь значимую роль играет лингвистический фактор в формировании идентичности человека.

Доклад доктора философских наук профессора Елизаветы Петровны Савруцкой и кандидата философских наук доцента Дмитрия Владимировича 
Семенова (Нижегородский государственный лингвистический университет им. Н.А. Добролюбова) так и назывался - «Язык как механизм сохранения исторической памяти». Докладчики последовательно доказали, что в современную эпоху повсеместной универсализации в сфере повседневной жизни, моды, кулинарии и т.д. язык практически в одиночку выполняет функцию генерации исторической памяти.

Доктор филологических наук профессор Московского городского педагогического университета Ирина Александровна Бубнова взглянула на проблему с иной стороны и осветила феномены искажения исторической памяти средствами языка. Инструментом такого искажения И.А. Бубнова считает сознательную смысловую подмену, т.е. так называемую управляющую семантику.

Кандидат философских наук доцент Марина Владимировна Федорова (Нижегородский государственный лингвистический университет им. Н.А. Добролюбова) в различных ракурсах представила особенности влияния языка цифровой культуры на сохранность культурной идентичности в современном мире. М.В. Федорова раскрыла диалектический и неодносложный характер соотношения цифровых технологий и лингвокультурной самобытности.

Часть выступающих сосредоточили внимание на вопросах функционирования языка в условиях межкультурного взаимодействия. Так, доктор педагогических наук профессор Томского государственного университета, научный сотрудник Томского научного центра СО РАН Ольга Андреевна Обдалова инициировала обсуждение проблемы понимания языковых актов, осуществляемых в условиях инокультурной реальности.

Доктор исторических наук профессор НГЛУ Сергей Васильевич Устинкин представил и обосновал критерии оценки эффективности политики лингвистической безопасности стран - участниц ОДКБ. Продолжая дискуссию, доктор исторических наук доцент Гульмира Дженишевна Джунушалиева (Кыргызско-российский славянский университет, г. Бишкек) на примере Кыргызской Республики показала, какие вызовы представляет для лингвистической безопасности поликультурная среда. Докладчик раскрыла противоречия, риски и преимущества, которые формирует многоэтничная сфера, для развития и сохранения языковой самобытности.

В свою очередь, преподаватель кафедры иностранных языков и литературы Ванадзорского государственного университета им. О. Туманяна (г. Ванадзор, Армения) Светлана Сережсаевна Берсегян показала, каким образом языки национальных культур трансформируются в современном армянском обществе. Особое внимание С.С. Берсегян уделила вопросам билингвизма и лингвокультурной диффузии.

В докладе Марины Юрьевны Соколовой (кандидат наук, университет штата Иллинойс, Чикаго) были освещены вопросы уже не би-, а трилингвизма. Докладчик раскрыла природу интегрированного знания нескольких языков при осмыслении структурных неоднозначностей армяно-русско-английскими трилингвами.

Доктор социологических наук, профессор, начальник ММ НИЛ «Технологии социально-гуманитарных исследований» (Нижегородский государственный лингвистический университет им. Н.А. Добролюбова) Ирина Александровна Савченко и старший преподаватель Приднестровского государственного университета им. Т.Г. Шевченко (Приднестровская Молдавская Республика) Виктория Владимировна Михайлова обратились к весьма необычной теме - лингвокультурной динамике современных непризнанных государств. Докладчики показали, что большинство таких государств (Абхазия, Приднестровье и др.) 
являются полиэтничными и многоязычными, в обществе преобладает билингвизм, что в значительной степени отражается на социокультурном развитии этих стран.

Тему взаимного влияния языков и культур продолжили доценты Ванадзорского государственного университета им. О. Туманяна. Так, Тарон Рудольфович Даниелян, Арен Мелсович Сантоян, Асмик Павловна Арутюнян, Тадевос Вруйрович Тадевосян показали, как армянский язык проявляет себя в медиасфере других культур. Используя многочисленные примеры, докладчики проиллюстрировали, каким образом реализуются армянские топонимы в гемеронимах инокультурной среды.

В ряде докладов подчеркивалось, насколько злободневными и актуальными являются вопросы языковой политики и лингвистической безопасности в США и странах Западной Европы. Так, кандидат филологических наук доцент Иркутского государственного университета Ольга Юрьевна Вербицкая обратилась к вопросам информационной безопасности, которые актуализируются при формировании общественного сознания современных американцев. Особое место языка в ментальном ландшафте современной Европы стало центральной идеей доклада кандидата филологических наук доцента Московского государственного университета им. М.В. Ломоносова Марины Михайловны Янгляевой. Кандидат филологических наук доцент Московского государственного университета им. М.В. Ломоносова Тамара Сергеевна Якова на примере Швейцарской конфедерации раскрыла специфику и тренды государственной языковой политики в мультикультурном сообществе.

В выступлениях поднимались вопросы лингвистической безопасности в контексте экономической и правовой культуры. Так, кандидат юридических наук доцент Нижегородского государственного лингвистического университета им. Н.А. Добролюбова Александр Всеволодович Никитин в фокусе социокультурного анализа раскрыл сущность языка закона как одного из гарантов лингвистической безопасности. Кандидат экономических наук доцент $\boldsymbol{H} \boldsymbol{u} \boldsymbol{a}$ Александровна Агеева (Восточно-Сибирский институт экономики и права, г. Иркутск) обосновала дихотомную природу лингвистической безопасности в контексте актуальной динамики экономической культуры. Н.А. Агеева показала, что, с одной стороны, характер современных экономических отношений связан с открытостью и интернационализацией, но с другой - с рисками утраты социально-экономической идентичности. В рамках экономической культуры вырабатываются ценностные ориентиры национальных экономик, связанные с духовной и лингвистической самоидентификацией участников международных рынков.

Не были обделены вниманием и вопросы лингвистической динамики на фоне глобальной пандемии COVID-19. Так, кандидат философских наук старший научный сотрудник ММ НИЛ «Технологии социально-гуманитарных исследований» Ольга Ивановна Димитричева (Нижегородский государственный лингвистический университет им. Н.А. Добролюбова) показала, как пандемия отражается в языке, продуцируя, в частности, появление специфических «ковидных» неологизмов.

Лингвистическая безопасность и языковая политика - не только социокультурные, но и социально-философские феномены, что и было обосновано в рамках научной дискуссии. Доктор философских наук Илья Анатольевич Треушников (Нижегородская академия МВД России) предложил философское обоснование лингвистической безопасности в рамках антиномии «Восток - Запад». Доктор философских наук, профессор, ведущий научный сотрудник ММ НИЛ «Технологии социально-гуманитарных исследований» (Нижегородский госу- 
дарственный лингвистический университет им. Н.А. Добролюбова) Станислав Леонидович Ивашевский рассмотрел одну из составляющих философии языка - философию имени. Особое внимание С.Л. Ивашевский уделил концепту философии имени в работах С.Н. Булгакова.

В докладе кандидата педагогических наук доцента Анатолия Анатольевича Лукутина и кандидата философских наук доцента Нижегородского государственного лингвистического университета им. Н.А. Добролюбова Дмитрия Владимировича Семенова речь шла об относительно новой отрасли знания философии безопасности. Раскрывая методологию этой отрасли, докладчики обосновали место концепта языковой политики в рамках категориального аппарата философии безопасности.

По результатам работы были сформулированы выводы и рекомендации. Докладчики пришли к мнению, что в многонациональных государствах баланс между языком титульной нации и языками этнических групп, проживающих на его территории, является залогом внутреннего единства, культурной интеграции и межнационального диалога, что следует признать важнейшим критерием эффективной стратегии лингвистической безопасности.

Язык и языковую политику следует рассматривать не только во внутриполитическом ключе, но и как важнейший ресурс «мягкой силы» и международной безопасности государства. Перспективным направлением обеспечения лингвистической безопасности может считаться повышение эффективности координации языковых политик государств, в первую очередь на площадках региональных интеграционных объединений.

На постсоветском пространстве русский язык выполняет функцию средства межэтнического общения, а также является основой интеграции различных этнокультурных групп в единую социокультурную русскоязычную общность. Российская языковая политика на пространстве ближнего зарубежья должна содействовать защите и повышению статуса русского языка в независимых постсоветских государствах.

Миграционные процессы в России пока не представляют опасности языковой ассимиляции или поглощения, не наблюдается и серьезная трансформация языковой структуры российского общества. Русский язык по-прежнему остается языком межэтнического общения как для народов России, так и для мигрантов. Основная проблема связана с утратой позиций русского языка на постсоветском пространстве и плохим знанием русского языка мигрантами, приезжающими в Россию, большинство которых не готовы встроиться в российское языковое пространство и продолжают общаться на родном языке. Опасная тенденция разделения на «своих» и «чужих» по принципу языка должна учитываться при формировании программ адаптации мигрантов.

Важным аспектом современной языковой политики является поддержание и развитие культуры владения языком, что должно находить выражение в программных документах, внутригосударственных планах и мероприятиях, стратегиях и практиках международного гуманитарного сотрудничества.

В целях совершенствования языковой политики в Российской Федерации следует, во-первых, проводить постоянный мониторинг общественных настроений в многонациональных регионах, и особенно в национальных республиках, для определения отношения к русскому и другим языкам народов России. Во-вторых, в школах с полинациональным составом необходимо создавать условия для изучения национальных языков (кружки, секции и т.д.). В-третьих, следует дополнить действующее законодательство нормативноправовыми актами, регулирующими использование государственного языка РФ в регионах страны. 
В федеральный закон «О безопасности» целесообразно внести положение о лингвистической безопасности как одной из составных частей национальной безопасности. Следует разработать доктрину лингвистической безопасности РФ и стратегию ее реализации.

С целью более глубокого исследования проблематики языковой политики и лингвистической безопасности необходимо развивать междисциплинарные связи, привлекая теоретический и методологический потенциал разных наук политологии, лингвистики, психологии, социологии, философии и других.

Таким образом, форум стал эффективной площадкой для научного обсуждения лингвистической безопасности в контексте актуальных социокультурных, экономических и политических изменений.

SAVCHENKO Irina Aleksandrovna, Dr.Sci. (Soc.), Head of the International Cross-Disciplinary Laboratory of Research Methods in Social Science; Professor of the Chair of Philosophy, Sociology and the Theory, Dobroljubov State Linguistics University of Nizhny Novgorod (31a Minina St, Nizhny Novgorod, Russia, 603155); Professor of the Chair of Philosophy, Nizhny Novgorod Academy of the Ministry of Internal Affairs of the Russian Federation (3 Ankudinovskoye Highway, Nizhny Novgorod, Russia, 603144; teosmaco@rambler.ru)

USTINKIN Sergei Vasil'evich, Dr.Sci. (Hist.), Professor; Dean of the Higher School of International Relations and World Politics; Director of the International Cross-Disciplinary Laboratory for Studies of Global and Regional Sociopolitical Processes, Dobroljubov State Linguistics University of Nizhny Novgorod (31a Minina St, Nizhny Novgorod, Russia, 603155); Director of the Volga Branch of the Federal Center of Theoretical and Applied Sociology, Russian Academy of Sciences (4 Holodny Lane, Nizhny Novgorod, Russia, 603000; sv.ustinkin@gmail.com)

\section{LANGUAGE POLICY AND LINGUISTIC SECURITY}

Abstract. The authors reveal the main issues discussed in the framework of the International Scientific and Educational Forum "Language Policy and Linguistic Security», which was held on October 1-2, 2020 in Nizhny Novgorod. The article shows the significance and relevance of research problems, conceptualized in the course of scientific discussion.

Keywords: language policy, linguistic security, linguistic analysis, social responsibility, sociolinguistics, ethnography of language, Russian language, identity, historical memory, semantics 